\title{
Detection of similarity and genetic distance between Iraqi chicken varieties and different standard strains
}

\author{
Th.A. Ezzulddin ${ }^{1}$, Dh.M. Jwher ${ }^{2}$ and S.A. Dabdoub ${ }^{3}$ \\ Department of Veterinary Public Health, College of Veterinary Medicine, University of Mosul, Mosul, Iraq \\ Email: ${ }^{1}$ thamer1961@ uomosul.edu.iq, ${ }^{2}$ Deea@gmx.us, ${ }^{3}$ solfiandabdoubI95I@yahoo.com
}

(Received September 18, 2019; Accepted October 10, 2019; Available online June 12, 2020)

\begin{abstract}
Forty-eight wing vein blood samples were collected from different locations of poultry rearing farms and back yard chickens of Nineveh governorate from the of local and exotic chicken. The chicken divided into twelve groups four birds each according to colors and phenotype for the local and exotic chicken respectively. Blood DNA was extracted and amplified by thermocycler apparatus and the electrophoresis was done using 1.2\% agarose gel for DNA bands exhibiting. The results showed high genetic similarity within the local chickens ranged between $0.78-0.96$ at an average of 0.88 , while it ranged between $0.73-0.86$ at an average of 0.78 in exotic breeds. The degree of similarity between Iraqi and exotic breeds was $0.74-0.88$ at average of 0.80 . The calculated average of differences among each of Iraqi and exotic chickens and in between were $0.12,0.22$ and 0.20 , respectively. However, the genetic distance within the local chicken, exotic breed and in between them was $0.128,0.24$ and 0.21 respectively. The study concluded that the genetic similarity was higher within local chicken groups than those of exotic breeds.
\end{abstract}

Keywords: RAPD-PCR, Polymorphism, Genetic similarity, Genetic distance, Iraqi chicken

DOI: 10.33899/ijvs.2019.126109.1235, @2020, College of Veterinary Medicine, University of Mosul.

This is an open access article under the CC BY 4.0 license (http://creativecommons.org/licenses/by/4.0/).

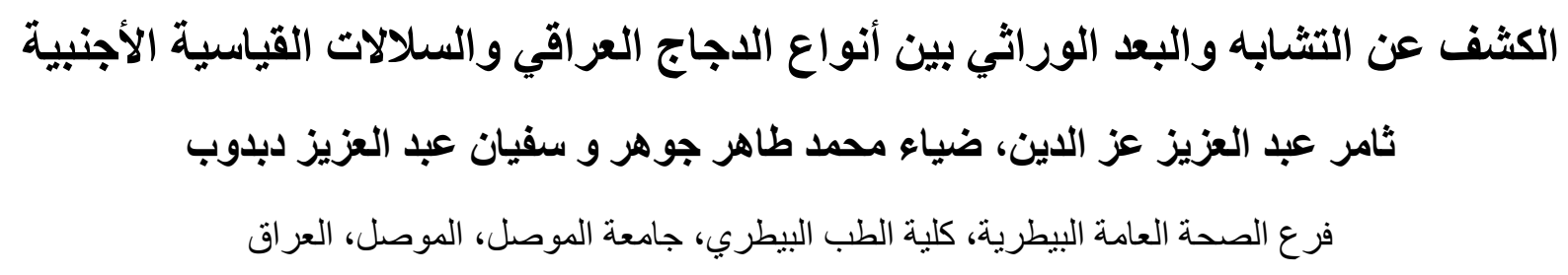

الخلاصة

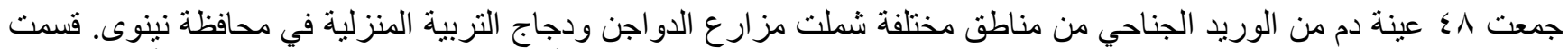

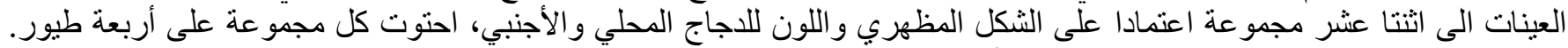

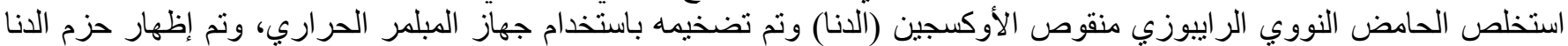

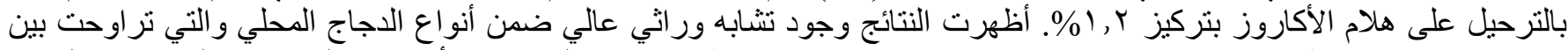

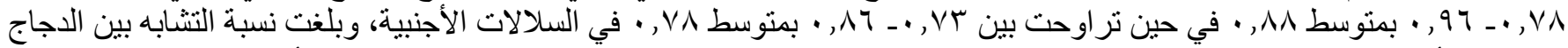

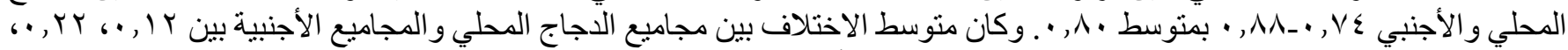

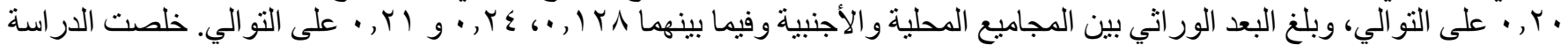
إلى أن التشابه الور اثي داخل المجاميع المحلية اعلى من التشابه بين مجاميع السلالات الأجنية النية.

\section{Introduction}

Over the last twenty-five years, molecular markers have been utilized to distinguish the different species of chicken. Before the biochemical and molecular markers were identified, the chicken species and varieties were characterized by phenotypic and quantitative traits value (1).

Molecular genetics has enabled opportunities to develop animal breeding programs by direct selection of genomic regions that serve economic traits (2). 
Finding out the polymerase chain reaction (PCR) had a great effect on the research eukaryotic genome and shared in the development and enforcement of various DNA markers (3).

The randomly amplified polymorphic DNA (RAPD) technique was described first by $(4,5)$, is a rapid and effective procedure that can be used to produce genotype specific banding patterns. Polymorphism of RAPD fragments is detected as a band's presence or absence and may result from deletion, insertion or differences in the nucleotide sequences in or between priming regions (6).

RAPD is an easy, quick and relatively low-cost screening that uses short oligonucleotide primers of arbitrary sequences to magnify anonymous fragments of genomic DNA (7).

Genetic information gives a unified approach for the variation within and between populations, which is affected by neither the environmental conditions nor the developmental stages of organisms.

Vanhala et al. (8) and Corzo et al. (9) denoted the usefulness of molecular information in the evaluation of the genetic variation and divergence. The Iraqi native chickens consist of different varieties descended from the red jungle fowl which mixed with different standard important strains, it is characterized by low egg production and body weight, but it is known by its resistance to diseases and extreme environmental conditions (10).

The objective of this study was to evaluate the genetic variability in a six breeder groups of the local chicken in Mosul city and the vicinity, which were divided according to the color (white, brown, black, black with white and naked neck, and mixed of colors) compared with New Hampshire, Japanese Bantam (chabo) Leghorn and cochin chicken based on RAPD-DNA markers, to generate genetic information on the local chicken structure for future development strategies.

\section{Materials and methods}

\section{Chicken groups}

This work consists of twelve deferent groups of local chicken and exotic standard strains as shown below. A total of 48 individuals of four from each type was utilized.

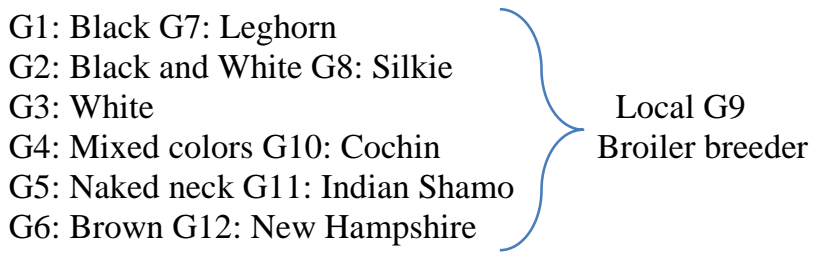

\section{DNA isolation}

Blood samples were collected into $5 \mathrm{ml}$ tubes containing EDTA. Genomic DNAs were obtained from blood samples (collected from wing vein) as described by Macrogen
Company Kit. The purity and concentration of DNA samples were checked by the Nano Drop ${ }^{\circledR}$ spectrophotometer. The same quantities of DNA from the birds of each group were mixed to perform the representative DNA.

\section{DNA amplification and electrophoresis condition}

Amplification reactions were carried out in a final volume of $20 \mu \mathrm{l}$ (Table 1).

Table 1: Amplification reactions

\begin{tabular}{lcc}
\hline Component & Volume & Final concentration \\
\hline HS Prime Taq Premix & $10 \mu \mathrm{l}$ & $1 \mathrm{X}$ \\
Primer & $3 \mu \mathrm{l}$ & $1 \mu \mathrm{M}$ \\
PCR grade water & $5 \mu \mathrm{l}$ & --- \\
DNA $(100 \mathrm{ng} / \mu \mathrm{l})$ & $2 \mu \mathrm{l}$ & $2 \mathrm{ng} / \mu \mathrm{l}$ \\
\hline Total & $20 \mu \mathrm{l}$ & \\
\hline
\end{tabular}

Amplification was achieved in a thermo cycler programmed for $10 \mathrm{~min}$ initial denaturation at $95^{\circ} \mathrm{C}$, then 40 cycles of $30 \mathrm{~s}$ at $95^{\circ} \mathrm{C}, 30 \mathrm{~s}$ at $34^{\circ} \mathrm{C}, 60 \mathrm{~s}$ at $72^{\circ} \mathrm{C}$, and $5 \mathrm{~min}$ final extension at $72{ }^{\circ} \mathrm{C}$.

\section{Agarose gel electrophoresis}

$1.2 \%$ agarose gel (Jena Bioscience, Germany). Loading $6 \mu$ of each PCR product. The electrophoresis was carried out at $3 \mathrm{~V} / \mathrm{cm}$ for 1 hour using power supply MP $300 \mathrm{~V}$ (Major Science, UK) containing $1 \mathrm{X}$ TBE buffer (GeNetBio, Korea). A $1 \mathrm{~kb}$ bp DNA marker, $4 \mu \mathrm{l}$ (Promega, USA) was used as a standard molecular weight marker.

\section{Gel documentation}

The gel was stained in a $200 \mathrm{ml}$ solution containing ethidium bromide $0.5 \mu \mathrm{g} / \mathrm{ml}$ and subsequently examined under UV light using the gel documentation system (BioDocAnalyze, Germany).

\section{Statistical Analysis}

To estimate the number of polymorphic and monomorphic bands. Bands were scored visually on the bases of their presence 1 or absence 0 . Genetic similarity (GS) was calculated using the following equation (11): GS= $2 \mathrm{Nab} / \mathrm{Na}+\mathrm{Nb}$.

Were Nab represent the entrant bands between the groups $\mathrm{a}$ and $\mathrm{b} . \mathrm{Na}+\mathrm{Nb}$ the total scrod bands for the same groups. Genetic polymorphism between groups was resolved as GP= 1- GS. Genetic distance was evaluated as (12): $G D=-\operatorname{In}(S)$. The phylogenetic tree was obtained on the base of genetic similarity using the SPSS Program (classify procedure).

\section{Results}

RAPD-PCR method was followed to study the genetic similarity and genetic distance of Iraqi local chicken and 
some imported exotic breeds. Nine random decanucleotide primers of the sequences, $\mathrm{GC}$ content and $\mathrm{Tm}{ }^{\circ} \mathrm{C}$ (table 2). A total of 60 loci included forty percentage of polymorphism were obtained.

The table 3, indicates the similarity and the differences between different chicken groups. The results expressed high homogeneity among Iraqi chicken groups which were varied from 0.78 to 0.96 with an average of 0.88 , while it ranged from 0.73 to 0.86 with middling 0.78 in the analogous exotic breeds. The similarity between the Iraqi local chicken versus pooled foreign groups was ranged from 0.74 to 0.88 with a median of 0.80 .

The highest genetic similarity within Iraqi chicken was found between G1and G3 (the white and the black chicken groups) which was 0.96 , while the lowest genetic similarity detected between G2 and G6 groups (black and white and brown) and was 0.78 . On the other hand, the highest degree of similarity between the Iraqi and exotic chicken groups occurred between G3 and G9 and was 0.88, and the lowest degree noticed between G5 and G10 of value 0.75. The calculated average of differences within each of Iraqi and exotic chickens and in between were $0.12,0.22$ and 0.20 , respectively.

Figure 1 shows the pattern of PCR product using the primer opp-17, clarify a part of genetic variation among the studied groups in eleven genetic loci included three of polymorphism bands. Concerning genetic distance which depends on the similarity degree, table (4) showed the genetic distance in calculated groups. The lowest genetic distance was found between G1 and G3 of Iraqi chicken and the farthest genetic distance was existed between the Silkie (Japanese mini chicken) and the Cochin (Huge Asian Chicken). The largest genetic distance among the whole chicken groups in this study was found between G8 and G11 of value 0.31 . As for the relationship between Iraqi and foreign chicken groups, the minimum genetic distance found between G3 and G9 was 0.13 , and the highest genetic distance represented between G5 and G10 was 0.29. The overall genetic distance within each of the local, standard strains of chicken, and in between was $0.128,0.24,0.215$, respectively.

Table 2: Genetic polymorphism analysis based on the primers used

\begin{tabular}{|c|c|c|c|c|c|c|}
\hline \multirow[b]{2}{*}{ Primer } & \multirow{2}{*}{ Sequence $5^{\prime}$ to $3^{\prime}$} & \multirow{2}{*}{$\% \mathrm{GC}$ content } & \multicolumn{2}{|c|}{ Number of loci } & \multirow{2}{*}{ Polymer Phism \% } & \multirow{2}{*}{$\mathrm{Tm}^{\circ} \mathrm{C}$} \\
\hline & & & polymorphic bands & Total bands & & \\
\hline BG-6 & CTG AGA CGG A & 60 & 3 & 8 & 37.5 & 32 \\
\hline OPA-6 & GGT CCC TGA C & 70 & 3 & 8 & 37.5 & 35 \\
\hline OPA-16 & AGC CAG CGA A & 60 & 5 & 10 & 50.0 & 32 \\
\hline OPB-19 & ACC CCC GAA G & 70 & 3 & 7 & 42.8 & 35 \\
\hline OPC-2 & GTG AGG CGT C & 70 & 2 & 6 & 33.3 & 35 \\
\hline OPC-3 & GGG GGT CTT T & 60 & 4 & 6 & 66.6 & 32 \\
\hline OPG-7 & GAA CCT GCG G & 70 & 4 & 8 & 50.0 & 35 \\
\hline OPP-14 & CCA GCC GAA C & 70 & 4 & 9 & 44.4 & 35 \\
\hline OPP-17 & TGA CCC GCC T & 70 & 3 & 11 & 27.3 & 35 \\
\hline Total & & & 24 & 60 & 40.0 & \\
\hline
\end{tabular}

Table 3: Genetic similarity and genetic variation values between chicken groups

\begin{tabular}{|c|c|c|c|c|c|c|c|c|c|c|c|c|}
\hline & G1 & G2 & G3 & G4 & G5 & G6 & G7 & G8 & G9 & G10 & G11 & G12 \\
\hline G1 & $\begin{array}{ll}* & 1\end{array}$ & 0.05 & 0.04 & 0.09 & 0.08 & 0.10 & 0.14 & 0.26 & 0.22 & 0.26 & 021 & 0.18 \\
\hline G2 & 0.95 & 1 & 0.17 & 0.18 & 0.18 & 0.22 & 0.23 & 0.19 & 0.20 & 0.15 & 0.15 & 0.16 \\
\hline G3 & 0.96 & 0.83 & 1 & 0.11 & 0.12 & 0.10 & 0.13 & 0.15 & 0.12 & 0.18 & 0.23 & 0.20 \\
\hline G4 & 0.91 & 0.82 & 0.89 & 1 & 0.10 & 0.17 & 0.18 & 0.16 & 0.17 & 0.20 & 0.18 & 0.12 \\
\hline G5 & 0.92 & 0.82 & 0.88 & 0.90 & 1 & 0.18 & 0.20 & 0.14 & 0.20 & 0.25 & 0.17 & 0.23 \\
\hline G6 & 0.90 & 0.78 & 0.90 & 0.93 & 0.82 & 1 & 0.24 & 0.24 & 0.19 & 0.14 & 0.17 & 0.14 \\
\hline G7 & 0.86 & 0.77 & 0.87 & 0.82 & 0.80 & 0.76 & 1 & 0.27 & 0.18 & 0.21 & 0.20 & 0.25 \\
\hline G8 & 0.74 & 0.81 & 0.85 & 0.84 & 0.76 & 0.75 & 0.73 & 1 & 0.22 & 0.26 & 0.27 & 0.14 \\
\hline G9 & 0.78 & 0.80 & 0.88 & 0.83 & 0.80 & 0.81 & 0.82 & 0.78 & 1 & 0.22 & 0.21 & 0.23 \\
\hline G10 & 0.74 & 0.85 & 0.82 & 0.80 & 0.75 & 0.79 & 0.79 & 0.74 & 0.78 & 1 & 0.15 & 0.22 \\
\hline G11 & 0.79 & 0.85 & 0.77 & 0.82 & 0.83 & 0.83 & 0.80 & 0.73 & 0.79 & 0.85 & 1 & 0.16 \\
\hline G12 & 0.82 & 0.84 & 0.80 & 0.78 & 0.77 & 0.80 & 0.75 & 0.86 & 0.77 & 0.78 & 0.84 & 1 \\
\hline
\end{tabular}

*The numbers above the axis represent the differences and the numbers below the axis represent the similarity 
Table 4: Genetic distance values between chicken groups

\begin{tabular}{|c|c|c|c|c|c|c|c|c|c|c|c|c|}
\hline & G1 & $\mathrm{G} 2$ & G3 & G4 & G5 & G6 & G7 & G8 & G9 & G10 & G11 & G12 \\
\hline & & & & & & & & & & & & \\
\hline G2 & 0.05 & & & & & & & & & & & \\
\hline G3 & 0.04 & 0.18 & & & & & & & & & & \\
\hline G4 & 0.09 & 0.20 & 0.12 & & & & & & & & & \\
\hline G5 & 0.08 & 0.20 & 0.13 & 0.11 & & & & & & & & \\
\hline G6 & 0.10 & 0.25 & 0.11 & 0.07 & 0.20 & & & & & & & \\
\hline G7 & 0.15 & 0.26 & 0.14 & 0.20 & 0.22 & 0.27 & & & & & & \\
\hline G8 & 0.30 & 0.21 & 0.16 & 0.17 & 0.27 & 0.29 & 0.31 & & & & & \\
\hline G9 & 0.25 & 0.22 & 0.13 & 0.19 & 0.22 & 0.21 & 0.20 & 0.25 & & & & \\
\hline G10 & 0.30 & 0.16 & 0.20 & 0.22 & 0.29 & 0.23 & 0.24 & 0.30 & 0.25 & & & \\
\hline G11 & 0.23 & 0.16 & 0.20 & 0.20 & 0.19 & 0.19 & 0.22 & 0.31 & 0.24 & 0.16 & & \\
\hline G12 & 0.19 & 0.17 & 0.22 & 0.25 & 0.26 & 0.22 & 0.29 & 0.15 & 0.26 & 0.25 & 0.17 & \\
\hline
\end{tabular}

As in the dendrogram below (Figure 2), the chicken groups were classified into two main clusters, the first one consisted of the six exotic strains, while the second represented the local chicken. Later, each cluster was divided into two sub- cluster branches. The dendrogram explains the relationship between study groups according to the degree of genetic distance.

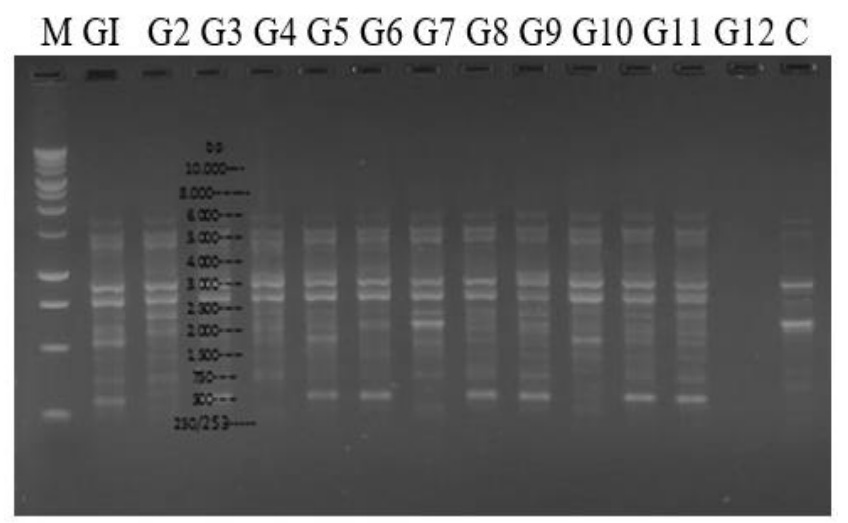

Figure 1: Electropherogram of DNA fragments obtained by PCR technique with opp-17 primer

\section{Discussion}

Although Iraqi chickens are characterized by a wide range of external phenotypes (13), low productivity of eggs and meat and other related quantitative traits (10), such characters may be due to their descendants from the same ancestors which were the red jungle fowl (14). Also, these birds did not subject to any selection program, despite their accidental crossbreeding with some imported breeds like Leghorn, New Hamshire, and certain broiler breeder. This information was approved by the obtained genetic distance data and the dendrogram.

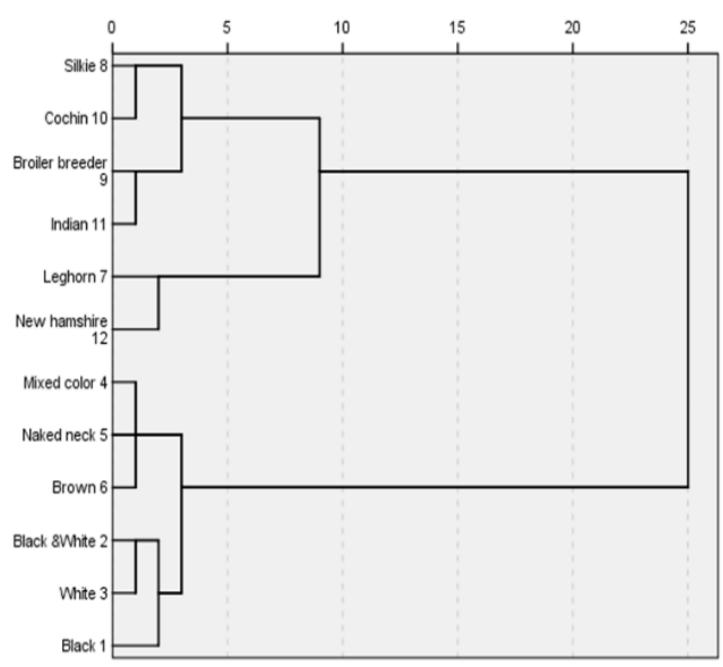

Figure 2: Dendrogram show genetic distance relationships

RAPD-PCR technique is an effective, simple and cheap tool for the determination of genetic diversity (15), which was demonstrated through the gained results that assured the limited differences among the local chicken groups. These findings are expected consequences of random mating for a long time. A total of 60 bands produced by 9 arbitrary primers resulting in different levels of similarity and genetic distance among all studied groups. It was found that the degree of similarity in the groups of Iraqi chickens 0.88 was higher than those of exotic chicken strains 0.80 . It is known that Iraqi chickens represent one population, some of which were subjected to hybridization. However, exotic chickens are definite breeds constrained by intensive selection programs for over 50 years, which caused have unique genotype translated to respective traits and ultimately to specific genetic identity (16).

The genetic distance depending entirely on the similarity and was found convergent in Iraqi chickens 0.128. However, 
this measurement was substantial in between the exotic chickens 0.24. A significant difference was noticed between the two main groups 0.215. Such difference could be attributed to the aforementioned reasons related to unique and uniform traits of each population, while the whole local chicken did not have any exclusiveness except the disease resistance which was acquired by prolonged environmental adaptation.

According to the attained information, the advantage of similarity and genetic distance should be utilized to improve the local chickens, intensive inbreeding program for several generations accompanied by selection should apply to arise pure genetic structures with partial improvement in production performance (17). Additionally, mixing with the males of egg production breed, continuous selection and performance evaluation should steadily go on.

\section{Conclusion}

The study concluded that the genetic similarity was higher within local chicken groups than those of exotic breeds

\section{Acknowledgements}

It is our pleasure to extend our great thanks and gratitude to the College of Veterinary Medicine at the University of Mosul for the support and facilities provided for the completion of the research

\section{Conflict of interest}

On behalf of all co-authors and stating that the submitted manuscript is the authors' original work, has not received prior publication and is not under consideration for publication elsewhere, permission has been received to use any material in the manuscript much as tables, figures etc. or no permissions have necessary to publish the authors' work.

\section{References}

1. Emara MG, Kim H. Genetic markers and their application in poultry breeding. Poult Sci. 2003;82:952-957. doi.org/10.1093/ps/82.6.952.
2. Dekkers JCM, and Hospital F. The use of molecular genetics in improvement of agricultural populations. Nat Rev Genet. 2002. 3:2232. doi.org/10.1038/nrg701

3. Salem HH, Ali BA, Huang TH, Qin DN. Use of randomly amplified polymorphic DNA (RAPD) markers in poultry research. Inter J Poult Sci. 2005;4(10):804-811. doi.org/10.3923/ijps.2005.804.811

4. Stepniak E, Zagalska M, Switonski M. Use of RAPD technique in evolution studies of four species in the family Canidae. J Appl Gen. 2002;43:489-499. doi.org/10.1186/1297-9686-35-6-573

5. Welsh J, McClelland M. Fingerprinting genome-using PCR with arbitrary primers. Nucleic Acids Res. 1990;18:7213-7218. doi.org/10.1093/nar/18.24.7213

6. Williams JG, Kubelik AR, Livak KJ, Rafalski JA, Tingey SV. DNA polymorphisms amplified by arbitrary primers are useful as genetic markers. Nucl Acid Res. 1990;18:6531-6535. doi.org/10.1093/nar/18.22.6531

7. Clark AG, Lanigan MS. Prospects for estimating nucleotide divergence with RAPDs. Mol Biol Evol. 1993;10:1096-1111. doi.org/10.1093/oxfordjournals.molbev.a040057

8. Gholizadeh M, Mianji Ghobadi A, Zadeh HS, Montazami Sh. Measurement of within and between genetic variability in duck breeds by RAPD markers. Pakistan J Bio Sci. 2007;10(6):982-985. doi.org/10.3923/pjbs.2007.982.985

9. Corzo A, Kidd MT, Pharr GT, Burgess SC. Initial Mapping of the Chicken blood plasma proteome. Inter J Poult Sci. 2004;3:157-162. doi.org/10.3923/ijps.2004.157.162

10. AL-Anbari EH. Association of coat plumage colors (CPC) for Iraqi local chicken and some productive performance trait by using some analysis parameters. Ann Trop Med Public Heal. 2020;23(06):88-94. doi.org/10.36295/asro.2020.23612

11. Sharma D, Appa Rao KBC, Singh RV, Totey SM. Genetic diversity among chicken breeds estimated through randomly amplified polymorphic DNA. Anim Biotechnol. 2001;12(2):111-20. doi.org/10.1081/abio-100108337

12. Nei M, Li WH. Mathematical modelling for studying genetic variation in terms of restriction endonucleases. Proc Natl Acad Sci. 1979;76:5269-5273. doi.org/10.1073/pnas.76.10.5269

13. Hikmmat AS, Alsanjary RB. Application of RAPD-PCR Technique for detection of genetic similarity in some local layer hens in Nineveh governorate. Basrah J Vet Res. 2018;17(3):162-171. http://basjvet.org/uplodes/pdf/1589047029.pdf

14. Al-Nasser A, Al-Khalaifa H, Al-Saffar A, Khalil F, Albahouh M, Ragheb G, Al-Haddad A, Mashaly M. Overview of chicken taxonomy and domestication. World's Poult Sci J. 2007;63:285-300. doi.org/10.1017/s004393390700147x

15. Singh RV, Sharma D. Within and between strain genetic variability in White Leghorn population detected through RAPD markers. Br Poult Sci. 2002;43:33-37. doi.org/10.1080/00071660120109854

16. Mollah MBR, Islam FB, Islam MS, Ali MA, Alam MS. Analysis of genetic diversity in Bangladeshi chicken using RAPD markers. Biotechnol. 2009;8(4):462-7. doi.org/10.3923/biotech.2009.462.467

17. Muir WM. Poultry genetics, breeding and biotechnology. $1^{\text {st }}$ ed. USA: CABI Publishing; 2003. 221-247 p. doi.org/10.1079/9780851996608.0000 